\title{
Distance Education in Poland, the Integrity of a student, the Pupil and Material Situation at Schools
}

\begin{abstract}
The text is raising the question of teaching by Internet, which reached peculiar scale in Poland, without any deeply reflexion about positive and negative effects of its using. In the article authors emphasize difficulties connected with using remote control - education, beginning from through lack of competences of average teacher in the scope of preparing e - learning materials, through dishonesty and impunity of students/pupils, closing on the difficulties connected with financial base (rather lack financial base) in the most educational institutions.
\end{abstract}

Key words: Internet, teaching, education, student, pupil.

Education in Poland has had a long tradition of pedagogical experimentation and innovation, starting from the first half of the 18th century and private education, through the Polish country side children's care centres, work schools, clandestine teaching and scouting methods, to the 21st century, and distance education [Kujawska 2009, p. 143].

Today, it is difficult for us to understand that 1.5 million years ago man, from the zoological point of view, was at the unique species level and had unique properties [Malinowski 2001, pp. 9-15; Frankiewicz 2013, p. 65]. Today, in the age of "knowledge and science" [Frączek 2009, p. 259], in the face of change and universal globalisation, the slogan a "unique species" tends to have extremely different meanings - the unique property is no longer speech and thinking, the 
up right gait, or having nails instead of claws [Malinowski 2001, p. 9]. Today, the principal value for the average human being is to have a television, a radio in the car, a mobile phone and access to a computer and the Internet [Frankiewicz 2013, p. 65].

Until recently the Internet has been regarded as something mysterious, accessible only to a few. It has secretly entered into our lives and almost all areas of our activities - from making purchases to sexual experiences, and from e-mail to education [Wallace 2001, p. 7].

The Internet explosion was so unexpected that we didn't have time to look at the new method of communication precisely, and we have failed to keep our distance and look at what an impact it has on our lives and behaviour [Wallace 2001, p. 7].

In recent years we have witnessed in Poland a significant and imminent decline in the level of education in schools at all levels. Knowledge learned at schools does not prepare young people for professional work, because chemistry, mathematics and physics are most disgusting subjects to students. History, biology and geography lessons have been significantly cut, and reduced to one lesson a week, and the teaching of the native language, as well as other modern languages, is limited to lecturing the basics of grammar and the preparation of a checklist, without any attempt at conversation. The effect of this conduct is the lowest percentage of young people studying science and technical sciences in Europe, and most intellectuals do not understand the basic laws of nature and technology and do not know the basic truths and historical facts [Denek 2009, p. 109].

Our education has been depreciated by politically-motivated decisions [Denek 2009, p. 109], and one of these was the introduction of so-called e-learning to Poland, that is distance education. Over the past three years, in at least some non-public Polish universities, and in a growing number of lower-level schools, distance education had been introduced, using a computer connected to the Internet, and all that as a result of the austerity policy of the Polish Government [Frankiewicz 2013, s. 69]. Nobody had bothered to think over whether this form of education will work out in Polish schools. Besides, it is more often heard that the classes in school facility should be regarded as at least the equivalent, and even partly replaced by virtual learning [Frankiewicz 2013, p. 69]. Thus, a classroom with a teacher is put in a partner status with the computer with the e-education platform [Frankiewicz 2013, p. 69; Kupisiewicz 1987, p. 187].

Unfortunately, what works out very well in other countries of Western Europe, Canada, Australia and the United States, having notable effects on education, in Poland deserves the name of an educational disaster. There are two reasons for this. The first, basic and elementary is the dishonesty of the student or pupil who takes the easy way out and does not even look at the materials prepared by 
the teacher, but just cribs the final test from a more ambitious colleague (rarely a friend), signs his/her name and sends as his/her own work, steadfastly waiting for a positive assessment [Frankiewicz 2013, p. 65]. The student or pupil neither analyses his/her work copied from his/her colleagues, nor pays attention to any errors made by the benevolent proxy and then he/she is terribly surprised by a negative assessment from the teacher and his/her own ignorance during the final exam.

An example of this conduct may be the results of an e-learning test on the History of Educational Thought in one of the Lublin tertiary schools. As it turned out, from among 97 of all e-learning platform users, 19 students did not log on to the subject course at all, while from among the remaining 78 students, only 19 looked at all the presentations prepared by the teacher and solved all 4 grading tests. In total, there were 24 presentations, arranged chronologically, from ancient times to the Age of the Enlightenment, and each of them contained material on approximately 90 slides with lots of written text in MS Office Power Point [Frankiewicz 2013, s. 69]. From among those 19 students, 16 devoted an average of one minute to familiarise themselves with each presentation and the same time to solve a single test, where each test consisted of 25 questions [Frankiewicz 2013, p. 70]. It follows irrefutably that from among 97 users only 3 solved e-learning properly [Frankiewicz 2013, p. 70; Kucha 2010/2011, /RKPS/, pp. 1-21]. This terrifying situation is presented in the following table.

Tab. 1 The final results of the students e-learning test

\begin{tabular}{|l|l|}
\hline Feature & Number of students \\
\hline All users & 97 \\
\hline Students not logged on at all & 19 \\
\hline $\begin{array}{l}\text { Logged on students, who did not look at all 24 } \\
\text { presentations }\end{array}$ & 78 \\
\hline $\begin{array}{l}\text { Logged on students, who devoted one minute to look } \\
\text { at each of the 24 presentations }\end{array}$ & 16 \\
\hline Logged on students, who solved e-learning properly & 3 \\
\hline
\end{tabular}

Source: R. Kucha, The list of the results with a commentary from the e-learning credit of the History of pedagogical thought in the form of 44 e-learning hours covering 24 subjects and 4 grading tests for the winter semester of the academic year 2010/2011 own materials, pp. 1-21 (RKPS). 
Chronicular honesty behoves us to add that during this e-learning test it also appeared that 24 students solved all the grading tests, while not looking at any of them, nor at any of the presentations, and 37 students solved all four tests, while not looking at any of the presentations [Kucha 2010/2011 /RKPS/, pp. 1-21]. The result of this avoidance of the huge part of the material contained in the e-education platform was 96 unsatisfactory grades in the final subject exam. Only one student received a satisfactory grade, which is the lowest among positive grades [Kucha 2010/2011, /RKPS/, pp. 1-6].

The second for the collapse of school or university education in Poland is the poor multimedia, software and facility infrastructure and financial resources of educational institutions, and the lack of an objective view of the differences between education in the sciences and humanities.

The supporters of the use of Information Technology in the classroom have found that it is a great support for education to force pupils to search and sort materials and material graphic design [Kwieciński, Śliwerski /ed./ 2003, p. 198]. Yet, there was a disregard for the diversity between mathematics, physics and chemistry - which inherently contain less content - and the humanities, where text cannot be ignored, because the whole of subject-related education is based on it [Kwieciński, Śliwerski /ed./ 2003, p. 199].

Polish educational institutions are often badly equipped with the latest technological achievements, and it happens that the only working computer is on the desk in the office of the Director of the institution, the multimedia projector is "temporarily" broken (in fact it is a "never-ending story"), and the software was updated several years ago. Even if the IT and multimedia infrastructure of the school is at the appropriate level, the software often appears to be very poor, which completely against the will of the teacher allows the copying of materials prepared by him/her and passing them on, unfortunately, rarely in their original form [Frankiewicz 2013, p. 71].

Nor can we forget that the computer skills of most teachers are generally below the average; sometimes they are elderly, visually-impaired people for which the preparation of materials for distance education becomes the proverbial real ordeal [Panasiuk 2005, p. 133; Frankiewicz 2013, p. 72]. Many teachers who are top-down forced to prepare e-learning materials devote most of their free time to these activities, leaving their private lives and personal interests to their own fate. There is a lack of specialist training for teachers and lecturers, which would show them simple ways of preparing multimedia presentations and other materials for remote education, so as to enable them to achieve satisfaction from their work, not just emotional but also financial, and not neglecting this situation their health and family lives [Frankiewicz 2013, p. 71].

A huge problem in Polish distance education is also the significant difference in software between that which is at school, and that which the teacher has 
privately at home. It very often happens that the e-learning platform at school has the Windows XP operating system, while a teacher at home prepares materials in the Windows Vista operating system, which is incompatible with XP. A more experienced person can try to save a file in the so-called compatibility mode, but it may turn out that some of its elements are unreadable to a student. In this situation it is difficult to require huge investments for the purchase of a new system (like Windows 7) by an institution. However, the situation of the teacher is also unenviable in this dialogue, because he/she must meet the formal requirements to prepare materials in a form that is fully readable for students, regardless of how long it takes him/her to unify all the elements of the file, as well as how low remuneration for this he/she receives [Frankiewicz 2013, p. 70]. Most often a teacher is paid not for the number of hours actually spent onelearning (preparation of materials, checking, assessment and comments sent to a pupil/student), but for the number of hours of top-down calculated by the school, which in no way corresponds to the real time spent on the computer.

A final objection to teaching through the Internet is the weakness of the e-learning programme itself, which often does not allow the introduction of teaching materials in any other form than MS Office Word or Power Point files. In addition, the system neither allows the use of hyperlinks to files or the use of gifs, nor forces individual work from the user. This means that in fact, we give pupils and students a freehand to copy materials required for a credit, and we give full permission to use the fruits of the work of others, completely thoughtlessly, and even worse, with impunity [Frankiewicz 2013, p. 72]. In Poland there is one more form of distance education, which is correspondence education. It has little in common with educational institutions and is not topdown forced from the student and it is an absolutely private initiative.

This is the so-called classical form of distance education, and has its roots in the mid-19th century, when a working day lasted "from morning to night" [Urbańczyk 1973, p. 350] - people busy working all day were not able to use the stationary forms of education and the only achievable option for them was correspondence education [Woźnicka 2000, p. 179].

Correspondence education, as well as education on the Internet, is based on the lack of direct contact between teacher and student, where the latter may elaborate teaching materials at home, at his/her own table, he/she is not hampered by time and he/she sets the pace of learning himself/herself. The student also has the opportunity to communicate with the teacher, sends him/her an assignment for assessment and has the right to receive comments [Woźnicka 2000, p. 180; Oesch 1950, p. 67].

In the Polish educational market, there is actually only one institution of this kind, which is the European School of Correspondence Education (ESKK). It 
conducts a wide variety of educational courses, ranging from high-school courses, a variety of language courses, from basic to advanced levels, to flower-arranging courses, psychological courses, or secretary/ director assistant courses [www. eskk.com.pl].

Each participant in the ESKK correspondence course receives for the duration of the learning period supporting materials in the form of exercise books, CDs, a multimedia dictionary for language courses and the so-called multimedia course, which allows learning on the computer screen (Kurs języka włoskiego dla początkujących ESKK). In addition, the student has his/her "personal teacher" [www.eskk.com.pl], who is available at any time by e-mail. Homework is not compulsory, but each exercise book has separate homework that can be done even within 12 months from the completion of the course [www.eskk.com.pl].

The materials made available to ESKK course participants are of very good quality, are prepared by professionally-trained staff and often exceed the value of materials used for learning in a regular educational institution. However, the disadvantage of such education is the fairly high cost and the lack of opportunities for immediate clarification of complex issues.

It is common knowledge that making use of the Internet as a means of communication is part of the practice of everyday life [Castells 2003, p. 219]. It appears, however, that this invention of civilisation significantly affects our mentality [Nalaskowski 2006, p. 41], because the ease of access to information means that significant changes occur in the values cherished by the students [Porzak 2005, p. 113; Lewandowska-Kidoń, Wosik-Kawala 2003, pp. 53-63]. In the modern Polish school ignorance is becoming a reason for pride, good grades are "uncool", and the teacher is a living being behind the desk, but a being embroiled in ministerial and school-board orders and prohibitions, students' rights and the orders of the management and parents [Frankiewicz 2013, p. 69]. The world of consumption is dominant, where the main category is pleasure and what gives satisfaction, and core values, like education, dignity, honour, truth, love and tolerance towards other people have stopped playing a significant role [Frankiewicz 2013, p. 69; Wróbel 2000, p. 127; Lewandowska-Kidoń, WosikKawala 2003, pp. 53-63].

Under such conditions and with such a low public awareness regarding the value of the Internet, with the absolutely unpunished dishonesty of the student and pupil and the thoughtless copying of materials, it can be definitely said that distance education in the Polish system of education has not passed the exam so far.

Wisdom feeds on knowledge and knowledge feeds on information. The path that leads towards wisdom is arduous, thorny and sometimes leads you astray. That is why we need a guide. In Poland, there is a call for a short cut: "if you 
have information, you will get knowledge yourself; schools and teachers are expendable" [Tanaś 2003, p. 117]. It has been forgotten that the use of computer technology in mass education should resemble the behaviour of the doctor who, when introducing a new medicine for therapy, needs to closely monitor all side effects [Hankała 2004, p. 82]. However, we should deeply reflecton the fact that the size of the Internet lies in the strength of the elimination of venerable institutions, and may yet prove to be disastrous in the consequences for the level of education of future generations of Poles.

\section{Bibliography}

Castells M. (2003), Galaktyka Internetu: Refleksje nad Internetem, biznesem i spoteczenistwem, Dom Wydawniczy REBIS, Poznań.

Denek K. (2009), Nię̧bedna modernizacja uniwersytetu [in:] Edukacja jutra. XV Tatrzańskie Seminarium Naukowe, vol. 1, ed. K. Denek, T. Koszczyc, P. Oleśniewicz, Wrocławskie Towarzystwo Naukowe, Wrocław, pp. 109-117.

Frankiewicz E. (2013), Wspótczesny twórczy nauczyciel a internetowa blokada intelektu [in:] Szkoła twórcza w odtwórczym śmiecie, ed. J. Krukowski, A. Włoch, Wydawnictwo Wydziału Pedagogicznego Uniwersytetu Pedagogicznego im. Komisji Edukacji Narodowej, Kraków, pp. 59-73.

Frączek Z. (2009), Przestrzeganie praw ucznia wyrazem świadomości wartości driecka [w:] Edukacja jutra. XV Tatrzańskie Seminarium Naukowe, vol. 1, ed. K. Denek, T. Koszczyc, P. Oleśniewicz, Wrocławskie Towarzystwo Naukowe, Wrocław, pp. 259-265.

Hankała A. (2004), Psychologiczne i spoteczne zagrożenia zwiqzane z zastosowaniem medión i technologii informatycznej w edukacji [in:] Pedagogika a środki informatyczne $i$ media, ed. M. Tanaś, Oficyna Wydawnicza „Impuls”, Kraków, pp. 73-83.

http://www.eskk.com.pl (last access 10 April 2015).

Jezzyk włoski dla początkujących ESKK - own materials.

Kucha R. (2010/2011), Lista wynikón z. komentarzem ₹ zajéc e-learningowych z. przedmiotu Historia Mysli Pedagogicznej, semestr zimowy roku akademickiego 2010/2011, pp. 1-21 - own materials /RKPS/.

Kujawska M. (2009), Innowacje i eksperymenty pedagogiczne po transformacji ustrojowej w Polsce [in:] Edukacja jutra. XV Tatrzańskie Seminarium Naukowe, vol. 1, ed. K. Denek, T. Koszczyc, P. Oleśniewicz, Wrocławskie Towarzystwo Naukowe, Wrocław, pp. 143-150.

Kupisiewicz C. (1987), Sžolnictwo w procesie przebudowy. Kierunki reform ónwiatowych w krajach upræemystowionych 1945-1985, WSiP, Warszawa.

Kwieciński Z., Śliwerski B. (ed.) (2003), Pedagogika. Podrecznike Akademicki (2003), t. 2, PWN, Warszawa.

Lewandowska-Kidoń T., Wosik-Kawala D. (2003), Wartości uznawane przez wychowankón placówee opiekunczo-nychowawcrych [in:] Praca opiekuńczo-nychowawcza, red. B. Wojciechowska-Charlak, Wszechnica Świętokrzyska, Kielce, ss. 53-63. 
Malinowski A. (2001), Człowiek w czasie i przestrzeni [in:] Biologiczne i medyczne podstawy rozwoju i wychowania, ed. A. Jaczewski, Wydawnictwo Akademickie ŻAK, Warszawa, pp. $9-15$.

Nalaskowski A. (2006), Drikość i zdziczenie, Oficyna Wydawnicza „Impuls”, Kraków.

Oesch E. (1950), Lexikon der Pedagogik, vol. 1, Verlag A. Franke, Bern.

Panasiuk B. (2005), Prezentacja multimedialna narzedziem pracy nauczyciela [in:] Wybrane problemy edukacji dzieci w przedszkolu i sqkole, ed. S. Guz, J. Andrzejewska, Wydawnictwo Naukowe UMCS, Lublin, pp. 133-141.

Porzak R. (2005), Wychowanie w szkole. Szanse i zagrożenia [in:] Rozwój i edukacja džiecka. Szanse i zagrożenia, ed. S. Guz, Wydawnictwo UMCS, Lublin, pp. 111-119.

Tanaś M. (2003), Edukacyjne konsekwencje rozwoju środków informatycznych [in:] Edukacja $i$ dialog w świecie przyszłości, ed. H. Kwiatkowska, M. Szybisz, Akademia Humanistyczna w Pułtusku, Pułtusk, pp. 110-122.

Urbańczyk F. (1973), Problemy oświaty dorostych, WSiP, Warszawa.

Wallace P. (2001), Psychologia Internetu, Dom Wydawniczy REBIS, Poznań.

Woźnicka E. (2000), Ksztatcenie korespondencyjne jako forma edukacji na dystans [in:] Pedagogiczne drogonskazy. Idee - metody - inspiracje, ed. B. Juraś-Krawczyk, B. Śliwerski, Oficyna Wydawnicza „Impuls”, Kraków, pp. 179-187.

Wróbel A. (2000), Pedagogika wobec medialnej manipulacji [in:] Pedagogiczne drogowskazy. Idee metody - inspiracje, ed. B. Juraś-Krawczyk, B. Śliwerski, Oficyna Wydawnicza „Impuls”, Kraków, pp. 127-130. 